\title{
Synthesis and anticancer activity of thiosubstituted purines
}

\author{
Alicja Kowalska ${ }^{1} \cdot$ Małgorzata Latocha $^{2} \cdot$ Krystian Pluta $^{1}$
}

Received: 13 October 2014/Accepted: 15 March 2015/Published online: 25 March 2015

(C) The Author(s) 2015. This article is published with open access at Springerlink.com

\begin{abstract}
New thiopurines with the propargylthio, pyrrolidinobutynylthio, sulfenamide, and sulfonamide groups in the pyrimidine ring were synthesized. The anticancer activity of these compounds and previously obtained 2- or 6-substituted azathioprine analogs and dialkylaminoalkylthiopurines were tested in vitro against three cell lines: glioblastoma SNB-19, melanoma C-32, and human ductal breast epithelial tumor T47D. 2-Chloro-7-methyl-6pyrrolidinobutynylthiopurine (5b) was the most potent compound against SBN-19 and C-32 cell lines with the activity similar to cisplatin $\left(\mathrm{EC}_{50}=5.00\right.$ and $7.58 \mu \mathrm{g} / \mathrm{ml}$, respectively). The dialkylaminoalkylthio derivatives $(\mathbf{4 b}, \mathbf{4 c}$, $\mathbf{4 e}$, and $\mathbf{4 f}$ ) showed good activity against SBN-19 cell line $\left(\mathrm{EC}_{50}<10 \mu \mathrm{g} / \mathrm{ml}\right)$. The azathioprine analogs (2a, 2b, and 3a) were more active than azathioprine against $\mathrm{SBN}-19$ and C-32 cell lines. The sulfenamide and sulfonamide derivatives of purine were very weak active against tested cell lines. All studied thiopurines were less toxic than cisplatin.
\end{abstract}

Keywords Azathioprine analogs .

Dialkylaminoalkylthiopurines · Purinesulfenamides ·

Purinesulfonamides $\cdot$ Anticancer activity

Electronic supplementary material The online version of this article (doi:10.1007/s00044-015-1364-2) contains supplementary material, which is available to authorized users.

Alicja Kowalska

kowalska@sum.edu.pl

1 Department of Organic Chemistry, School of Pharmacy with the Division of Laboratory Medicine, The Medical University of Silesia, Jagiellońska 4, 41-200 Sosnowiec, Poland

2 Department of Cell Biology, School of Pharmacy with the Division of Laboratory Medicine, The Medical University of Silesia, Jedności 8, 41-200 Sosnowiec, Poland

\section{Introduction}

The sulfur-containing purines: 6-mercaptopurine, 6-thioguanine, and azathioprine, have been considered as important and effective drugs used in cancer chemotherapy, for immunosuppression in kidney or heart transplantation and autoimmune diseases (Steurer et al., 2006; Hawwa et al., 2008; Relling et al., 2013; Rao et al., 2013). 6-Mercaptopurine is widely used as an antileukemic agent in the lymphoproliferative disorders, including lymphoma, childhood acute lymphoblastic leukemia, and other neoplastic conditions (Hawwa et al., 2008; Prima et al., 2013; Miron et al., 2009). Azathioprine, but also 6-mercaptopurine exert immunosuppressive effects and are the treatments of choice for severe chronic inflammatory diseases such as rheumatoid arthritis, ulcerative colitis, Crohn's disease, inflammatory bowel diseases, systemic lupus erythematosus, and multiple sclerosis (Aldinucci et al., 2010; Colombel et al., 2010; Daehn and Karran, 2009). Various pharmacological effects of synthetic thiopurines including antiviral, antibacterial, antitumor, and antifungal activity (Lech-Maranda et al., 2006; Rao et al., 2013) were developed for treatment of patients with infections of human immunodeficiency virus (HIV) and infections caused by herpes and hepatitis virus (Rao et al., 2013; Schow et al., 1997; Chang-Hyun et al., 2001).

However, the use of thiopurines is limited by their toxicities, which include hepatotoxicity, myelosuppression, pancreatitis, and allergic reactions (Prima et al., 2013). For this reason, many thiopurine derivatives and analogs have been synthesized for evaluation of their biological activities and reduced toxicity. Recently, 9-substituted derivatives of 6-(t-butoxycarbamylaminohexyl)thiopurine were obtained which showed moderate antibacterial activity (Rao et al., 2013); a series of 6-mercaptopurine analogs with 1,2,3-triazole or steroid rings exhibited 
promising antimalarial and antileishmanial activities (Corrales et al., 2011); and biologically active 6-allyldithiopurine and its riboside inhibited cell proliferation and induced apoptosis (Miron et al., 2009).

Heterocyclic sulfonamides are used as carbonic anhydrase inhibitors, antibacterial, anti-inflammatory, analgesic, hypoglycemic, antifungal, and antiviral agent (Joseph et al., 2010; Guzel et al., 2009; Azab et al., 2013; El-Sayed et al., 2011; Veisi et al., 2011). It is known that aryl and heteroaryl sulfonamides may act as antitumor agents through perturbation of cell cycle in the $G_{1}$ phase, distribution of microtubule assembly, or angiogenesis inhibition. They reverse the effect of tumor acidification, consequently inhibit the growth of cancer cell, and suppress tumor invasion mediated by the carbonic anhydrase active side $\left(\mathrm{Zn}^{2+}\right)$ and so inhibit the catalytic ability of this enzyme (El-Sayed et al., 2011). Indisulam (E7070) is a novel sulfonamide anticancer agent currently in phase II clinical development for the treatment of several types of cancer. It was shown to act as a nanomolar inhibitor of carbonic anhydrase isoform IX (Sławiński et al., 2013; Mirian et al., 2011).

The sulfamoyl group has been extensively utilized as an activity-modifying substituent in many different classes of drugs. The synthesis of 2-substituted 7- or 9-methylpurines containing a sulfanilamide group at the positions 2,6 , or 8 of the purine ring with moderate antibacterial activity was reported by the reaction of chloropurines with sodium sulfanilamide (Beaman et al., 1966). Structural modification of the amino group at C-6 atom of adenosine leads to selective $\mathrm{A}_{1}$ receptor agonists, while modification at $\mathrm{C}-2$ atom confers high potency and selectivity on $\mathrm{A}_{2 \mathrm{~A}}$ receptors. The synthesis of N-9- and 6-amino monosulfonyladenine and disulfonyladenine derivatives and its sulfonylated nucleoside with high potency and selectivity on $A_{1}$ and $A_{2 A}$ receptor agonists has been described (Zinic et al., 2001). A number of 6-sulfenamide, sulfinamide, and sulfonamide derivatives of 6-mercaptopurine, 6-thioguanine, and related ribonucleosides have been synthesized and evaluated for antileukemic activity in mice (Revankar et al., 1990). It is quite interesting that a subtle change to an oxidized sulfur atom in the form of sulfonamide resulted in a new group of purine derivatives possessing significant antitumor properties. Majority of the tested compounds exhibited very significant anti-L1210 cell activity (Revankar et al., 1990; Robins et al., 1991).

Oligonucleotides containing 1-alkynyl-6-thiopurine or 6-thioguanine bases demonstrate potent antiviral activity in several assays, including the human immunodeficiency virus reverse transcriptase enzyme assay (Broom et al., 1997). The purine derivatives possessing the alkynyl groups at position 6 are cytokinin analogs with profound plant growth-stimulating effect and have attracted considerable interest as potential anticancer compounds. All 6-phenylacetylenes and certain enyne of the purine are highly toxic against K-562 cells and exhibit cytotoxic activity against a human chronic myelogenous leukemia cell line comparable to well-known anticancer drugs (6-mercaptopurine and fludarabine) (Brathe et al., 2003). Many adenine and adenosine derivatives with 2-, 6-, or 8-alkynyl substituents are selective adenosine subtypes $A_{1}$, $\mathrm{A}_{2 \mathrm{~A}}, \mathrm{~A}_{2 \mathrm{~B}}$, and $\mathrm{A}_{3}$ receptor antagonists. 2-Alkynyl-8-aryl adenine derivatives bear methyl or an amide moiety at the position 9, as $\mathrm{A}_{2 \mathrm{~B}}$ receptor antagonists have hypoglycemic activity and may be used as antidiabetic agents (Harada $e t$ al., 2001). Stimulating $A_{2 A}$ receptor by 2-adenosine propargyl phenyl ether composition resulted in vasodilating activity and potential of using in coronary artery disease (Zablocki et al., 2001). Introduction of alkynyl chains on C-8 atom of adenosine led to very selective antagonists of the $\mathrm{A}_{3}$ receptor (Volpini et al., 2001). Some 2-alkynyl and 2,(6-amino)dialkynyl adenosine derivatives show high affinity and different degrees of selectivity for $\mathrm{A} 1, \mathrm{~A}_{2 \mathrm{~A}}$, and $\mathrm{A} 3$ receptor (Volpini et al., 2001).

Our previous research demonstrated the effective synthesis of thiosubstituted purines such as 2- or 6-substituted azathioprine analogs (Kowalska and Pluta, 2008; Kowalska et al., 2009) and dialkylaminoalkylthiopurines (Kowalska and Pluta, 2012). The aim of this study was to elaborate synthesis of new thiopurines with the propargylthio, pyrrolidinobutynylthio, sulfenamide, and sulfonamide groups in the pyrimidine ring, to examine anticancer activity of not only those compounds but also previously synthesized thiopurines and to discuss the structure-activity relationship.

\section{Result and discussion}

\section{Chemistry}

All thiosubstituted 7-methylpurines were obtained from 2-substituted 7-methylpurine-6-thiones 1a-c and 7-methylpurine-2,6-dithiones 1d. Purinyl sulfides 2-4 with the pharmacophoric 1-methyl-4-nitroimidazol-5-yl and dialkylaminoalkyl groups in positions 2 and 6 were obtained according to the procedures published previously (Kowalska and Pluta, 2008; Kowalska et al., 2009; Kowalska and Pluta, 2012). The alkynylthio derivatives 5 were obtained from 2-chloro derivative 1a and propargyl bromide and further via Mannich reaction with pyrrolidine (Scheme 1).

The traditional and general method for preparing sulfonamides is based on reaction of sulfonyl chloride with ammonia or amines. The aryl sulfonyl chlorides may be obtained from thiols, sulfides, thioacetals, or thiocarbamines by oxidative chlorination with chlorine gas in aqueous acid (Veisi et al., 2011; Mirian et al., 2011; Ashfaq et al., 2013; Narasaiah et al., 2012; Rehman et al., 2012). 2-Chloro-7-methyl-6-purinethione $\mathbf{1 a}$ was chosen as a 
model compound to prepare S-benzylthiopurine 6. It is known that azinesulfonyl chlorides with the chlorosulfonyl group in aza-activated positions readily lose sulfur dioxide to form chloroazines (Beaman and Robins, 1961; Beaman, 1963; Revankar et al., 1990).

Two-step synthesis of purinesulfonamide $\mathbf{8}$ via oxidation and chlorination of sulfide $\mathbf{6}$ with chlorine in acetic acid and subsequent transformation of sulfonyl chloride $\mathbf{7}$ with ammonia, diethylamine, or aniline failed. In this case, the highly instable chlorosulfonyl group lost sulfur dioxide, and resulted chloropurine reacted with ammonia and amines to give 2-chloro-6-amine derivatives 9a-c with $71-86 \%$ yield (Scheme 2).

Therefore, the sulfonamide compounds were obtained from purinethione via amination and oxidation. The procedure of S-amination of azinethiones with chloramine solution has been widely used in the preparation of purine-, pyridine-, pyrimidine-, and benzothiazolesulfenamides (Revankar et al., 1990; Robins et al., 1991; Hurley and Robinson, 1965; Schoenwald et al., 1984). For 2-Substituted 7-methyl-6-purinethiones 1a-c, S-amination with a chloramine solution at $0{ }^{\circ} \mathrm{C}$ to sulfenamide 10a-c in $85-92.5 \%$ yield was carried out. In the case of purinedithione 1d, two products were obtained: disubstituted compound as the main product, purine-2,6-disulfenamide 10e $(66 \%$ yield) and purine-6-sulfenamide 10d $(17.5 \%$ yield). Treatment of sulfenamides $\mathbf{1 0}$ with 4 molar equivalent of 3-chloroperoxybenzoic acid (MCPBA) at room temperature in ethanol gave purinesulfonamides 8ad in 66-79 \% yield. Lesser equivalents of MCPBA led to sulfenamides (Revankar et al., 1990).

The structure of all new compounds was determined by the spectral data analysis: ${ }^{1} \mathrm{H}$ and ${ }^{13} \mathrm{C}$ NMR, EI, CI or FAB MS, and HR MS. ${ }^{1} \mathrm{H}$ NMR spectra of new compounds revealed $\mathrm{H}-8, \mathrm{NCH}_{3}$ proton signals, and protons from C-2 $\left(\mathrm{OCH}_{3}, \mathrm{SCH}_{3}\right)$ and $\mathrm{C}-6\left(\mathrm{CH}_{2} \mathrm{C}_{6} \mathrm{H}_{5}, \mathrm{NH}_{2}, \mathrm{~N}\left(\mathrm{C}_{2} \mathrm{H}_{5}\right)_{2}\right.$, $\mathrm{NHC}_{6} \mathrm{H}_{5}, \mathrm{SCH}_{2} \mathrm{CCH}, \mathrm{SCH}_{2} \mathrm{CCCH}_{2} \mathrm{NC}_{4} \mathrm{H}_{8}, \mathrm{SNH}_{2}, \mathrm{SO}_{2}$ $\mathrm{NH}_{2}$ ) substituents. ${ }^{13} \mathrm{C}$ NMR spectra showed primary, secondary, tertiary, and quaternary carbon signals. In order to assign all of these signals, 2D NMR techniques (HSQC - the primary, secondary, and tertiary carbon atoms connected with the hydrogen atoms and HMBC-the primary, tertiary, and quaternary carbon atoms connected with the hydrogen atoms via two and mainly three bonds) for selected compounds (5a, 10e) were used. For compounds $\mathbf{5 a}$, in the HSQC spectrum the $\mathrm{H}-8$ proton at $8.59 \mathrm{ppm}$ correlated with the signal at $151.09 \mathrm{ppm}(\mathrm{C}-8)$, the $\mathrm{SCH}_{2}$ proton at $4.22 \mathrm{ppm}$ correlated with the signal at $18.09 \mathrm{ppm}$ $\left(\mathrm{C}, \mathrm{SCH}_{2}\right)$, and the proton at $4.04 \mathrm{ppm}\left(\mathrm{NCH}_{3}\right)$ correlated with the signal at $34.84 \mathrm{ppm}\left(\mathrm{C}, \mathrm{NCH}_{3}\right)$. The $\mathrm{HMBC}$
Scheme 1 Synthesis of 2- or 6-substituted azathioprine analogs 2, 3,

dialkylaminoalkylthiopurines $\mathbf{4}$, propargylthio- and pyrrolidinobutynylthiopurines $\mathbf{5}$

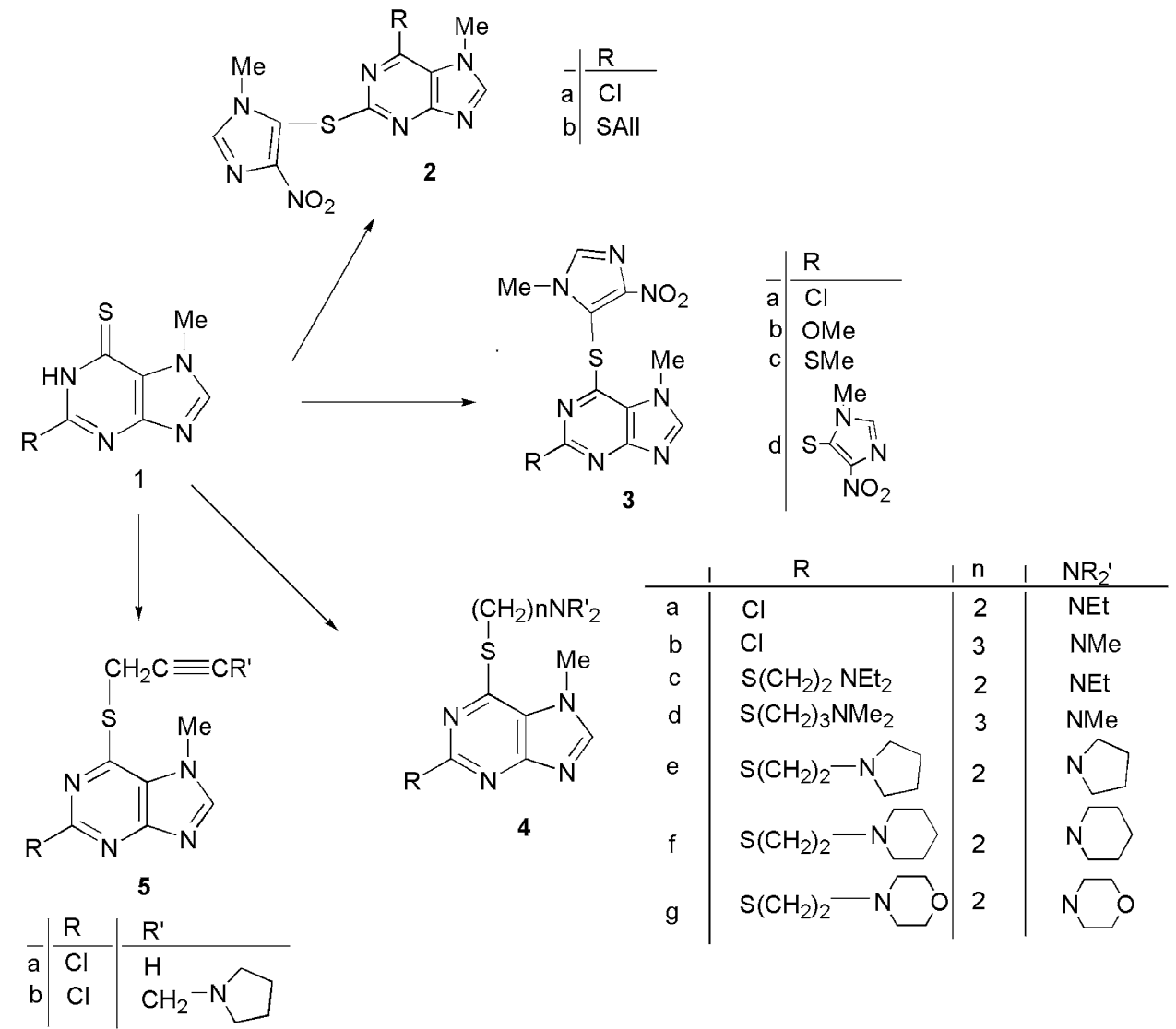




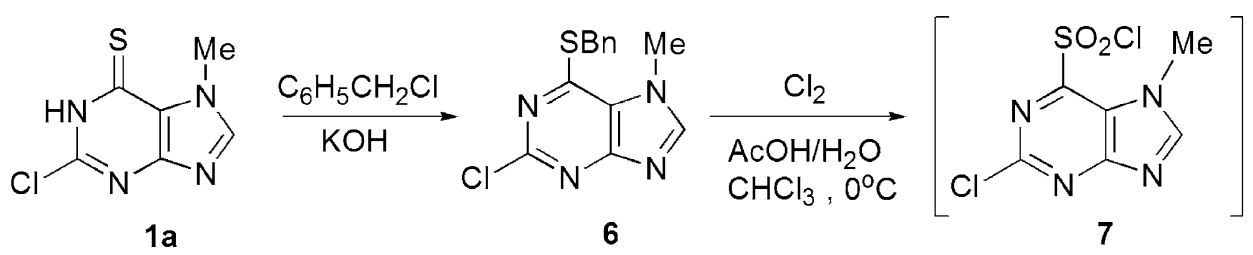

$1 \mathrm{a}$

6

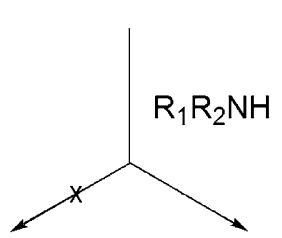<smiles>[R]N([R])S(=O)(=O)c1nc(Cl)nc2ncn(C)c12</smiles><smiles>[R2]N([R2])c1nc(Cl)nc2ncn(C)c12</smiles>

9

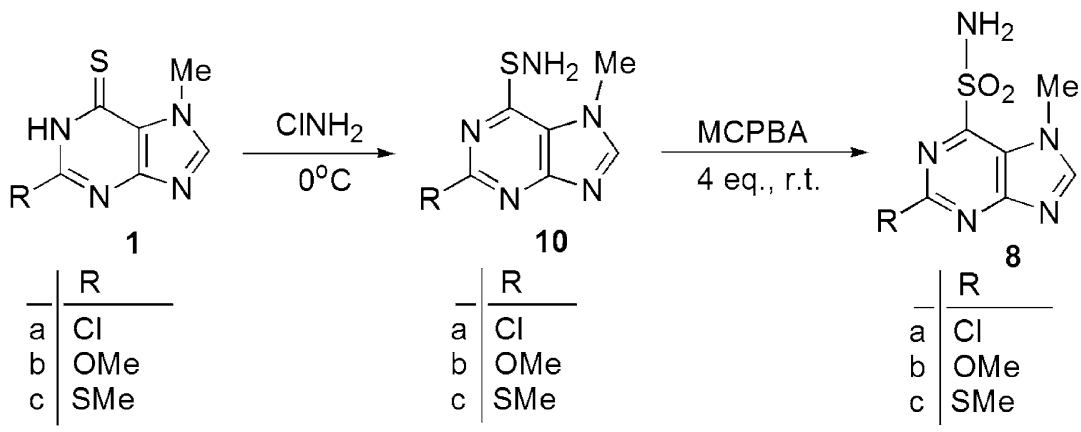<smiles>Cn1cnc2nc(S)nc(S)c21</smiles>

MCPBA<smiles>Cn1cnc2nc(S(N)(=O)=O)nc(S(N)(=O)=O)c21</smiles>

8d

Scheme 2 Synthesis of amine 9, sulfenamide 10, and sulfonamide 8 derivatives of purines 
spectrum revealed correlation via three bonds between the $\mathrm{H}-8$ proton at $8.59 \mathrm{ppm}$ and the carbon signals at $34.84 \mathrm{ppm}\left(\mathrm{C}, \mathrm{NCH}_{3}\right)$, at $123.16 \mathrm{ppm}(\mathrm{C}-5)$, and at $160.52 \mathrm{ppm}$ (C-4). The proton signal at $4.22 \mathrm{ppm}(\mathrm{H}$, $\mathrm{SCH}_{2}$ ) correlated with the signals of carbon atoms via two bonds at $79.55 \mathrm{ppm}(\mathrm{C}, \underline{\mathrm{CCH}})$ and via three bonds at $74.67 \mathrm{ppm}(\mathrm{C}, \mathrm{CH})$ and at $153.99 \mathrm{ppm}$ (C-6). The proton signal at $4.04 \mathrm{ppm}\left(\mathrm{H}, \mathrm{NCH}_{3}\right)$ correlated via three bonds with the signals at $123.16 \mathrm{ppm}$ (C-5) and at $151.09 \mathrm{ppm}$ (C-8). The proton-carbon correlation was presented in Scheme 3.

\section{Anticancer activity}

For the biological tests, 20 thiopurines of five types were selected:

(a) the azathioprine analogs containing the methylnitroimidazolylthio group in position 2 (compounds $\mathbf{2 a}$, $\mathbf{2 b})$, in position 6 (3a-c), and in both positions (3d),

(b) the dialkylaminoalkylthio derivatives containing that substituent with an open-chain amine group in positions $6(\mathbf{4 a}, \mathbf{4 b}), 2$ and $6(\mathbf{4 c}, 4 \mathbf{d})$ and with a cyclic amine group (pyrrolidine, piperidine, and morpholine) in positions 2 and $6(\mathbf{4 e -} \mathbf{g})$,

(c) the alkynylthio derivatives containing the propynylthio (5a) and pyrrolidinobutynylthio (5b) groups,

(d) the sulfenamide derivative (10a),

(e) the sulfonamide derivatives with that group in positions $6(\mathbf{8 a}-\mathbf{c})$, and 2 and $6(\mathbf{8 d})$.

The anticancer activity of the obtained compounds was investigated in vitro using cultured glioblastoma SNB-19, melanoma C-32, and human ductal breast epithelial tumor T47D cell lines. Normal human fibroblasts (HFF-1) were used as a control, and azathioprine and cisplatin as reference drugs. Table 1 contains the activity of thiopurines as the $\mathrm{EC}_{50}$ values.

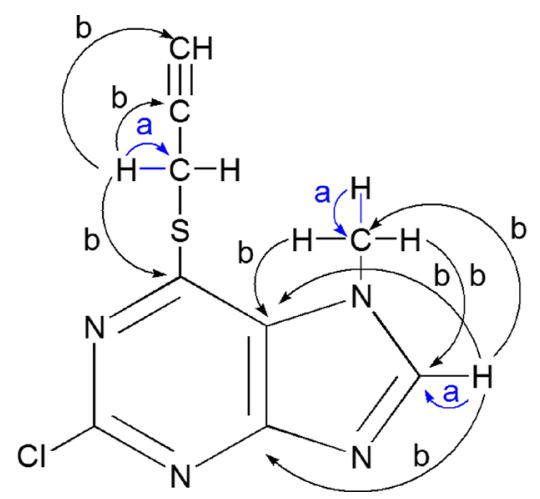

a - HSQC b - HMBC

Scheme 3 2D NMR experiments for compound $\mathbf{5 a}$
The most active was 2-chloro-7-methyl-6-pyrrolidinobutynylthiopurine $(\mathbf{5 b})$ with the $\mathrm{EC}_{50}$ values of 5.00 and $7.58 \mu \mathrm{g} / \mathrm{ml}$ against SNB-19 and C-32 cell lines, comparable to the cisplatin effect. This compound exhibited good selectivity and low toxicity, being weak active against T47D cell line and normal fibroblasts HFF-1. The introduction of the pyrrolidine ring to the alkynyl chain enhanced the activity (compound $\mathbf{5 b}$ vs. 5a).

Good activity against SNB-19 cell line was observed for the dialkylaminoalkylthio derivatives $(\mathbf{4 b}, \mathbf{4 c}, \mathbf{4 e}$, and $\mathbf{4 f})$ with the $\mathrm{EC}_{50}$ values below $10 \mu \mathrm{g} / \mathrm{ml}$. The compounds with the ethyl chain were more active than those with the propyl chain. The most active was compound $4 \mathbf{e}$ with the two pyrrolidinoethylthio groups. The activity against other cell lines was lesser as well as their toxicity.

The azathioprine analogs with the imidazolylthio group in position 2 were more active than those with that group in position 6 with an exception of compound (3a) which exhibited good activity against $\mathrm{C}-32$ cell line. The most active azathioprine analogs $(\mathbf{2 a}, \mathbf{3 a})$ possessed the chlorine atom in position 2 or 6 . Both compounds were more active than azathioprine (against first two cell lines) and compounds containing the methoxyl and thioalkyl groups $(\mathbf{2 b}$, 3b, 3c). Compound 3d with two imidazolylthio groups turned out to be unexpectedly inactive. In our opinion, such an effect was the result of the unusual spatial arrangement of those groups directed to N-1 atom with the donor-acceptor interaction between the imidazole rings, as it was observed in X-ray analysis of the monocrystal 3d (Kowalska et al., 2009).

The sulfenamide and sulfonamide derivatives are very weak active or inactive. The glioblastoma SNB-19 was most sensitive and breast tumor T47D least sensitive cell line for thiopurines. All studied compounds were less toxic than cisplatin.

\section{Conclusion}

In search for novel thiopurine derivatives, we described synthesis of 2-chloro-6-alkynylthio-7-methylpurines 5a, 5b from 2-chloro derivative and propargyl bromide and further via Mannich reaction with pyrrolidine. Other types of thiopurines bearing the sulfenamide 10a-e and sulfonamide 8a-d groups were obtained through $\mathrm{S}$-amination of purinethiones 1a-d and oxidation with 3-chloroperoxybenzoic acid.

New thiopurines $\mathbf{5}, \mathbf{8}$, and 10, previously synthesized azathioprine analogs $\mathbf{2}$ and $\mathbf{3}$, and dialkylaminoalkylthiopurines 4 were investigated as antitumor agents. The most potent compound against SBN-19 and C-32 cell lines was 2-chloro-7-methyl-6-pyrrolidinobutynylthiopurine $\mathbf{5 b}$ 
Table 1 Antiproliferative activity of thiopurines

\begin{tabular}{|c|c|c|c|c|}
\hline \multirow[t]{2}{*}{ Compound } & \multicolumn{4}{|c|}{ Antiproliferative activity $\mathrm{EC}_{50}(\mu \mathrm{g} / \mathrm{ml})$} \\
\hline & SBN-19 & $\mathrm{C}-32$ & T47-D & HFF-1 \\
\hline $2 \mathbf{a}$ & 17.92 & 21.77 & 41.11 & $>50$ \\
\hline $\mathbf{2 b}$ & 33.26 & 35.33 & 49.60 & $>50$ \\
\hline 3a & 30.38 & 12.79 & $>50$ & 34.93 \\
\hline $3 \mathbf{b}$ & $>50$ & $>50$ & $>50$ & $>50$ \\
\hline $3 c$ & $>50$ & $>50$ & 48.63 & $>50$ \\
\hline 3d & $>50$ & $>50$ & $>50$ & $>50$ \\
\hline $4 a$ & 28.77 & 22.47 & 41.27 & $>50$ \\
\hline $4 b$ & 8.45 & $>50$ & $>50$ & $>50$ \\
\hline $4 c$ & 9.82 & 33.55 & 24.00 & 40.00 \\
\hline $4 d$ & 36.28 & $>50$ & $>50$ & $>50$ \\
\hline $4 e$ & 7.95 & 27.05 & 38.40 & 35.41 \\
\hline $4 f$ & 9.18 & 21.80 & 32.25 & 45.50 \\
\hline $4 g$ & $>50$ & $>50$ & $>50$ & $>50$ \\
\hline $5 a$ & 30.95 & 35.35 & 44.30 & 48.95 \\
\hline $5 b$ & 5.00 & 7.58 & 46.00 & 43.12 \\
\hline $8 \mathbf{a}$ & $>50$ & $>50$ & $>50$ & $>50$ \\
\hline $8 b$ & 35.02 & $>50$ & $>50$ & $>50$ \\
\hline $8 c$ & $>50$ & $>50$ & $>50$ & $>50$ \\
\hline $8 d$ & $>50$ & $>50$ & $>50$ & $>50$ \\
\hline $10 a$ & $>50$ & $>50$ & $>50$ & $>50$ \\
\hline Azathioprine & 37.20 & 35.62 & 39.00 & 55.88 \\
\hline Cisplatin & 4.45 & 6.28 & 8.79 & 30.00 \\
\hline
\end{tabular}

with the activity similar to cisplatin. The dialkylaminoalkylthio derivatives $\mathbf{4 b}, \mathbf{4 c}, \mathbf{4 e}$, and $\mathbf{4 f}$ showed good activity against SBN-19 cell line. The azathioprine analogs $\mathbf{2 a}, \mathbf{2 b}$, and $\mathbf{3 a}$ were more active than azathioprine against SBN-19 and C-32 cell lines. The sulfenamide and sulfonamide derivatives of thiopurine were very weak active against tested cell lines. All studied thiopurines were less toxic than cisplatin.

\section{Experimental}

6-Substituted derivatives of 7-methyl-2-(1-methyl-4-nitroimidazol-5-ylthio)purines $\mathbf{2 a - b}$ were prepared from 7-methyl-2,6-di(1-methyl-4-nitroimidazol-5-ylthio)purine 3d exploiting different reactivity of the imidazolylthio groups toward nucleophilic reagents (Kowalska et al., 2009). 2-Substituted derivatives of 7-methyl-6-(1-methyl-4nitroimidazol-5-ylthio)purines 3a-d were obtained in the reaction of 6-purinethiones with 5-chloro-1-methyl-4-nitroimidazole in $70 \%$ ethanol (Kowalska and Pluta, 2008). 2-Substituted 6-(dialkylaminoalkylthio) 4a-b and 2,6-bis (dialkylaminoalkylthio) derivatives $\mathbf{4 c}-\mathbf{g}$ were obtained via the direct S-dialkylamination of the appropriate purinethiones (Kowalska and Pluta, 2012). All commercially available organic solvents and reagents were from Sigma-Aldrich and Chempur and were used without further purification.

The melting points were determined in open capillary tubes on a Boetius melting point apparatus and were uncorrected. ${ }^{1} \mathrm{H}$ NMR spectra were recorded on a Bruker AVANS 300 spectrometer operating at $300 \mathrm{MHz}$ and $75 \mathrm{MHz}$ for ${ }^{1} \mathrm{H}$ and ${ }^{13} \mathrm{C}$ nuclei, respectively, in deuterochloroform and dimethyl sulphoxide- $d_{6}$ with tetramethylsilane as internal standard. Shifts were given in ppm, coupling constant $(\mathrm{J})$ values were presented in hertz $(\mathrm{Hz})$, and the abbreviations were as follows: s (singlet), $\mathrm{d}$ (doublet), $\mathrm{t}$ (triplet), and $\mathrm{m}$ (multiplet). Electron impact (EI MS), chemical ionization (CI MS), fast atom bombardment (FAB MS), and high-resolution (HR MS) (in the $m$-nitrobenzyl alcohol and glycerol matrix) mass spectra were run on a Finnigan MAT 95 spectrometer at $70 \mathrm{eV}$. The reactions were monitored by thin-layer chromatography (TLC) using aluminum sheets coated with silica gel $60_{\mathrm{F} 254}$ (Merck) and chloroform-ethanol (9:1) as the solvents. Purity of the synthesized compounds was confirmed by TLC in the same way. Spots were detected by their absorption under UV light $(\lambda=254 \mathrm{~nm})$, and the chromatograms were further visualized by iodine vapor. Column chromatography separations were carried out with Merck Kieselgel 60 or aluminum oxide 90 (Merck) using a mixture of chloroform-ethanol (99:1, v/v) as an eluent.

Synthesis of 2-chloro-6-(prop-2-ynylthio)-7-methylpurine $5 \boldsymbol{a}$ Propargyl bromide $(0.17 \mathrm{~g}, 1.44 \mathrm{mmol})$ was added to a solution generated from the reaction of 2-chloro-7methyl-6-thiopurine $(0.2 \mathrm{~g}, 1 \mathrm{mmol})$ with t-BuOK $(0.16 \mathrm{~g}$, $1.44 \mathrm{mmol}$ ) in $10 \mathrm{ml}$ of DMF at room temperature for $0.5 \mathrm{~h}$. The reaction mixture was stirred for an additional $24 \mathrm{~h}$ at room temperature and then added to $25 \mathrm{ml}$ of water. The resulted solid was filtered off and washed with water to give compound 5a. It was obtained as a pale yellow solid $(0.22 \mathrm{~g}, 92 \%)$; mp $183-184{ }^{\circ} \mathrm{C}(\mathrm{EtOH}) ;{ }^{1} \mathrm{H}$ NMR (DMSO-d ${ }_{6}$ ), $\delta: 3.26(\mathrm{t}, J=2.2 \mathrm{~Hz}, 1 \mathrm{H}, \mathrm{CH}), 4.04$ (s, $\left.3 \mathrm{H}, \mathrm{NCH}_{3}\right), 4.22\left(\mathrm{~d}, J=2.2 \mathrm{~Hz}, 2 \mathrm{H}, \mathrm{SCH}_{2}\right), 8.59(\mathrm{~s}, 1 \mathrm{H}$, $\mathrm{H}-8) ;{ }^{13} \mathrm{C}$ NMR (DMSO-d 6 ), $\delta: 18.09\left(\mathrm{CH}_{2}, \mathrm{SCH}_{2} \mathrm{CCH}\right)$, $34.84\left(\mathrm{CH}_{3}, \mathrm{NCH}_{3}\right), 74.67\left(\mathrm{CH}, \mathrm{SCH}_{2} \mathrm{CCH}\right), 79.55(\mathrm{C}$, $\mathrm{SCH}_{2} \mathrm{CCH}$ ), 123.00 (C, C-5), 151.09 (CH, C-8), 152.28 (C, C-2), 153.99 (C, C-6), 160.52 (C, C-4); HSQC NMR, $\delta$ : $8.59(\mathrm{H}-8)$ correlated with $151.09(\mathrm{C}-8), 4.22\left(\mathrm{H}, \mathrm{SCH}_{2}\right)$ correlated with $18.09\left(\mathrm{C}, \mathrm{SCH}_{2}\right), 4.04\left(\mathrm{H}, \mathrm{NCH}_{3}\right)$ correlated with $34.84\left(\mathrm{C}, \mathrm{NCH}_{3}\right)$; HMBC NMR, $\delta: 8.59(\mathrm{H}-8)$ correlated with $34.84\left(\mathrm{C}, \mathrm{NCH}_{3}\right), 123.00(\mathrm{C}-5)$, and 160.52 (C-4), $4.22\left(\mathrm{H}, \mathrm{SCH}_{2}\right)$ correlated with $79.55(\mathrm{C}, \mathrm{CCH})$, $74.67(\mathrm{C}, \mathrm{CH})$, and $153.99(\mathrm{C}-6), 4.04\left(\mathrm{H}, \mathrm{NCH}_{3}\right)$ correlated with 123.00 (C-5) and 151.09 (C-8); EIMS m/z 238 $[\mathrm{M}]^{+}$(34.5), $240[\mathrm{M}+2]$ (12), 203 [M-Cl] (39), $133[\mathrm{M}-\mathrm{Cl}$, 
$\left.-\mathrm{SCH}_{2} \mathrm{CCH}\right]$ (55), $39\left[\mathrm{CH}_{2} \mathrm{CCH}\right]$ (100); HREIMS m/z $[\mathrm{M}]^{+}$calcd. for $\mathrm{C}_{9} \mathrm{H}_{7} \mathrm{ClN}_{4} \mathrm{~S} 238.0079$, found 238.0076.

Synthesis of 2-chloro-6-(4-N-pyrrolidinylbut-2-ynylthio)-7methylpurine $\mathbf{5} \boldsymbol{b}$ To a mixture of propargyl derivative $\mathbf{5 a}$ $(0.24 \mathrm{~g}, 1 \mathrm{mmol})$ and paraformaldehyde $(0.06 \mathrm{~g}, 2 \mathrm{mmol})$ in $5 \mathrm{ml}$ of dry dioxane, pyrrolidine $(0.14 \mathrm{~g}, 2 \mathrm{mmol})$ and $\mathrm{CuCl}$ $(0.01 \mathrm{~g})$ were added. The reaction mixture was stirred at temperature $70{ }^{\circ} \mathrm{C}$ for $2 \mathrm{~h}$. After cooling, the resulting solid was filtered off and purified by column chromatography (silica gel, $\mathrm{CHCl}_{3}, \mathrm{CHCl}_{3}-\mathrm{EtOH}, 99: 1 \mathrm{v} / \mathrm{v}$ ) to give compound 5b. It was obtained as a pale yellow solid $(0.31 \mathrm{~g}, 96 \%)$; mp $129-130{ }^{\circ} \mathrm{C}(\mathrm{EtOH}) ;{ }^{1} \mathrm{H}$ NMR $\left(\mathrm{CDCl}_{3}\right), \delta: 2.13(\mathrm{~m}, 8 \mathrm{H}$, $\left.4 \mathrm{CH}_{2}\right), 3.12\left(\mathrm{t}, J=2.2 \mathrm{~Hz}, 2 \mathrm{H}, \mathrm{SCH}_{2}\right), 3.62(\mathrm{t}, J=2.2 \mathrm{~Hz}$, $\left.2 \mathrm{H}, \mathrm{CCH}_{2}\right), 4.19\left(\mathrm{~s}, 3 \mathrm{H}, \mathrm{NCH}_{3}\right), 8.25(\mathrm{~s}, 1 \mathrm{H}, \mathrm{H}-8) ;{ }^{13} \mathrm{C} \mathrm{NMR}$ (DMSO-d $\left.\mathrm{d}_{6}\right), \delta: 18.77\left(\mathrm{CH}_{2}, \mathrm{SCH}_{2} \mathrm{CC}\right), 23.68\left(2 \mathrm{CH}_{2}\right), 34.86$ $\left(\mathrm{CH}_{3}, \mathrm{NCH}_{3}\right), 42.58\left(\mathrm{CH}_{2}, \mathrm{CCH}_{2}\right), 51.86\left(2 \mathrm{CH}_{2}, \mathrm{NCH}_{2}\right)$, $79.15\left(\mathrm{C}, \mathrm{SCH}_{2} \mathrm{CC}\right), 80.01$ (C, $\left.\mathrm{SCH}_{2} \mathrm{CC}\right), 123.16$ (C, C-5), 151.08 (CH, C-8), 152.35 (C, C-2), 154.24 (C, C-6), 160.50 (C, C-4); CIMS m/z $322[\mathrm{M}+1]^{+}$(6.5), $324[\mathrm{M}+1+2]$ (2.5), $167\left[\mathrm{M}+1-\mathrm{SCH}_{2} \mathrm{CCCH}_{2} \mathrm{NC}_{4} \mathrm{H}_{8}\right] \quad(9.5), 72 \quad\left[\mathrm{C}_{4} \mathrm{H}_{8} \mathrm{NH}_{2}\right]^{+}$ (100); HRFABMS m/z $[\mathrm{M}+\mathrm{H}]^{+}$calcd. for $\mathrm{C}_{14} \mathrm{H}_{17} \mathrm{ClN}_{5} \mathrm{~S}$ 322.0893 found 322.0893 .

Synthesis of 2-chloro-6-benzylthio-7-methylpurine 6 2Chloro-6-benzylthio-7-methylpurine 6 was prepared from 2-chloro-7-methyl-6-purinethione $1 \mathbf{1 a}(0.2 \mathrm{~g}, 1 \mathrm{mmol})$ by alkylation with benzyl chloride $(0.25 \mathrm{~g}, 2 \mathrm{mmol})$ at room temperature in $4 \%$ aqueous $\mathrm{KOH}$ solution $(5 \mathrm{ml})$. After $30 \mathrm{~min}$, the crude product was precipitated, filtered off, washed with water, and crystallized from benzene. It was obtained as a pale yellow solid $(0.265 \mathrm{~g}, 91.5 \%)$; mp 131-132 ${ }^{\circ} \mathrm{C}$ (benzene); ${ }^{1} \mathrm{H}$ NMR $\left(\mathrm{CDCl}_{3}\right), \delta: 4.07$, (s, 3H, $\left.\mathrm{NCH}_{3}\right), 4.64\left(\mathrm{~s}, 2 \mathrm{H}, \mathrm{CH}_{2}\right), 7.38\left(\mathrm{~m}, 5 \mathrm{H}_{\text {arom }}\right), 7.98(\mathrm{~s}, 1 \mathrm{H}$, $\mathrm{H}-8) ;{ }^{13} \mathrm{C}$ NMR (DMSO-d 6 ), $\delta: 33.39\left(\mathrm{CH}_{2}, \mathrm{SCH}_{2}\right), 34.84$ $\left(\mathrm{CH}_{3}, \mathrm{NCH}_{3}\right), 122.72(\mathrm{C}, \mathrm{C}-5), 127.98(\mathrm{CH}, \mathrm{p}-\mathrm{CH}), 128.99$ $(2 \mathrm{CH}, \mathrm{m}-\mathrm{CH}), 129.84(2 \mathrm{CH}, \mathrm{o}-\mathrm{CH}), 137.12\left(\mathrm{C}, \mathrm{CCH}_{2}\right)$, 150.79 (CH, C-8), 152.26 (C, C-2), 155.46 (C, C-6), 160.33 (C, C-4); EIMS m/z $290[\mathrm{M}]^{+}$(100), $292[\mathrm{M}+2]$ (28.5), $199\left[\mathrm{M}-\mathrm{C}_{6} \mathrm{H}_{5} \mathrm{CH}_{2}{ }^{+}\right.$(87); HREIMS m/z $\left[\mathrm{M}^{+}\right]$calcd. for $\mathrm{C}_{13} \mathrm{H}_{11} \mathrm{ClN}_{4} \mathrm{~S} 290.0392$ found 290.0385 .

\section{Chlorination and amination of 2-chloro-6- benzylthio-7-methylpurine 6}

The chlorinolysis was carried out by passing chlorine gas into a stirred mixture composed of 2-chloro-6-benzylthio7-methylpurine $6(0.29 \mathrm{~g}, 1 \mathrm{mmol}), 3 \mathrm{ml}$ of chloroform, and $3 \mathrm{ml}$ of $80 \%$ acetic acid cooled at $5{ }^{\circ} \mathrm{C}$. The passage of chlorine gas was continued for $30 \mathrm{~min}$, and then the mixture was poured into $10 \mathrm{ml}$ of ice water. The chloroform layer was separated, and aqueous layer was extracted with chloroform $(2 \times 5 \mathrm{ml})$. The chloroform extracts were combined, washed with water, dried over anhydrous sodium sulfate, and evaporated in vacuo to give an oil residue. In order to remove benzyl acetate and benzyl chloride, the residue was triturated with ice-cold dry ether and the ether layer was separated. The mixture of obtained oil $(0.26 \mathrm{~g}$, $1 \mathrm{mmol})$, and $25 \%$ aqueous ammonia $(2.5 \mathrm{ml})$ or diethylamine $(0.22 \mathrm{~g}, 3 \mathrm{mmol})$ in $10 \% \mathrm{NaOH}$ solution or aniline $(0.19 \mathrm{~g}, 2 \mathrm{mmol})$ in $2.5 \mathrm{ml}$ of benzene was stirred at $40-45^{\circ} \mathrm{C}$ for $2-6 \mathrm{~h}$. The resulted solid was filtered off (in the case of the reaction with ammonia, the excess of ammonia was removed in vacuo and the residue was diluted with water up to volume $2.5 \mathrm{ml}$ ) to give compounds $\mathbf{9 a - c}$. Products were purified by a column chromatography (aluminum oxide, $\mathrm{CHCl}_{3}-\mathrm{EtOH}, 99: 1 \mathrm{v} / \mathrm{v}$ ) to give:

2-Chloro-6-amine-7-methylpurine $9 \boldsymbol{a}$ was obtained as a white solid (0.15 g, $82 \%)$; mp 248-249 ${ }^{\circ} \mathrm{C}(\mathrm{EtOH})$, lit. mp $250{ }^{\circ} \mathrm{C}$ (Adams and Whitmore, 1945); ${ }^{1} \mathrm{H}$ NMR (DMSO$\left.\mathrm{d}_{6}\right), \delta: 3.97\left(\mathrm{~s}, 3 \mathrm{H}, \mathrm{NCH}_{3}\right), 7.46\left(\mathrm{~s}, 2 \mathrm{H}, \mathrm{NH}_{2}\right), 8.20(\mathrm{~s}, 1 \mathrm{H}$, $\mathrm{H}-8) ;{ }^{13} \mathrm{C}$ NMR (DMSO-d 6 ), $\delta: 34.29\left(\mathrm{CH}_{3}, \mathrm{NCH}_{3}\right)$, 111.12 (C, C-5), 147.27 (CH, C-8), 153.03 (C, C-2), 153.17 (C, C-6), 161.50 (C, C-4); EIMS m/z 183 [M] ${ }^{+}(100), 185$ [M+2] (29); HREIMS m/z [M] ${ }^{+}$calcd. for $\mathrm{C}_{6} \mathrm{H}_{6} \mathrm{ClN}_{5}$ 183.0311 found 183.0307 .

2-Chloro-6-diethylamine-7-methylpurine $9 \boldsymbol{b}$ was obtained as a white solid $(0.20 \mathrm{~g}, 84 \%)$; mp $106-107{ }^{\circ} \mathrm{C}$ (EtOH), lit. mp $107{ }^{\circ} \mathrm{C}$ (Adams and Whitmore, 1945); ${ }^{1} \mathrm{H}$ NMR (DMSO-d $\left.)_{6}\right), \delta: 1.17\left(\mathrm{t}, J=7.7 \mathrm{~Hz}, 6 \mathrm{H}, 2 \times \underline{\mathrm{CH}_{3}}\right.$ $\left.\mathrm{CH}_{2} \mathrm{~N}\right), 3.52\left(\mathrm{q}, J=7.7 \mathrm{~Hz}, 4 \mathrm{H}, 2 \times \mathrm{CH}_{3} \mathrm{CH}_{2} \mathrm{~N}\right), 30.94(\mathrm{~s}$, $\left.3 \mathrm{H}, \mathrm{NCH}_{3}\right), 8.37$ (s, $\left.1 \mathrm{H}, \mathrm{H}-8\right) ;{ }^{13} \mathrm{C}$ NMR $\left(\mathrm{DMSO}_{\mathrm{d}}\right), \delta$ : $12.93\left(2 \mathrm{CH}_{3}, \mathrm{NCH}_{2} \mathrm{CH}_{3}\right), 35.63\left(\mathrm{CH}_{3}, \mathrm{NCH}_{3}\right), 44.32\left(2 \mathrm{CH}_{2}\right.$, $\left.\mathrm{NCH}_{2} \mathrm{CH}_{3}\right), 114.45$ (C, C-5), 149.30 (CH, C-8), 151.81 (C, C-2), 154.70 (C, C-6), 163.03 (C, C-4); EIMS m/z 239 [M] ${ }^{+}$ (19), $241[\mathrm{M}+2]$ (6); 210 [M- $\mathrm{C}_{2} \mathrm{H}_{5}$ ], (100); HREIMS m/z $[\mathrm{M}]^{+}$calcd. for $\mathrm{C}_{10} \mathrm{H}_{14} \mathrm{ClN}_{5} 239.0937$ found 239.0935.

2-Chloro-6-phenylamine-7-methylpurine $9 \boldsymbol{c}$ was obtained as a white solid $(0.18 \mathrm{~g}, 69 \%)$; mp $202-203{ }^{\circ} \mathrm{C}$. (EtOH); ${ }^{1} \mathrm{H}$ NMR $\left(\mathrm{CDCl}_{3}\right), \delta: 3.96\left(\mathrm{~s}, 3 \mathrm{H}, \mathrm{NCH}_{3}\right), 6.84(\mathrm{~s}, 1 \mathrm{H}, \mathrm{NH})$, $7.23\left(\mathrm{t}, J=7.20 \mathrm{~Hz}, 1 \mathrm{H}, \mathrm{p}-\mathrm{C}_{6} \mathrm{H}_{5}\right), 7.40(\mathrm{t}, J=7.20 \mathrm{~Hz}$, $\left.2 \mathrm{H}, \mathrm{m}_{-} \mathrm{C}_{6} \mathrm{H}_{5}\right), 7.52\left(\mathrm{~d}, J=7.20 \mathrm{~Hz}, 2 \mathrm{H}, \mathrm{o}-\mathrm{C}_{6} \mathrm{H}_{5}\right), 7.90$ (s, $1 \mathrm{H}, \mathrm{H}-8) ;{ }^{13} \mathrm{C}$ NMR (DMSO-d $\left.\mathrm{d}_{6}\right), \delta: 34.63\left(\mathrm{CH}_{3}, \mathrm{NCH}_{3}\right.$ ), 112.40 (C, C-5), 123.17 (2CH, m-CH), $124.61(\mathrm{CH}, \mathrm{p}-\mathrm{CH})$, 129.06 (2CH, o-CH), 138.97 (C, CNH), 148.47 (CH, C-8), 149.75 (C, C-2), 152.29 (C, C-6), 162.07 (C, C-4); FABMS $\mathrm{m} / \mathrm{z} 260[\mathrm{M}+1]^{+}(100), 262[\mathrm{M}+1+2]$ (31.5); HREIMS $\mathrm{m} / \mathrm{z}[\mathrm{M}]^{+}$calcd. for $\mathrm{C}_{12} \mathrm{H}_{10} \mathrm{ClN}_{5} 259.0625$ found 259.0626 .

\section{General synthesis of 2-substituted 7-methyl-6- purinesulfenamide 10a-e}

A solution of commercial $\mathrm{NaOCl}(14.5 \%, 1.7 \mathrm{ml})$ and $1.7 \mathrm{ml}$ of water was cooled to $0{ }^{\circ} \mathrm{C}$ in an ice- $\mathrm{NaCl}$ bath. 
Ammonium hydroxide $(25 \%, 2 \mathrm{ml})$ was similarly cooled and added with stirring to the bleach solution. The mixture was stirred at -5 to $0{ }^{\circ} \mathrm{C}$ for $15 \mathrm{~min}$ and then allowed to cool to $0{ }^{\circ} \mathrm{C}$ solution of 2-substituted 7-methyl-6-purinethione 1a-d (2 mmol) in $10 \% \mathrm{KOH}(5 \mathrm{ml})$ was dropped. The mixture was stirred in stoppered flask for $30 \mathrm{~min}$ at temperature -5 to $0{ }^{\circ} \mathrm{C}$. The reaction mixture was initially clear, light yellow solution, but after $30 \mathrm{~min}$ a solid began separating. After allowing the reaction mixture to stand at room temperature for an additional $1 \mathrm{~h}$, the precipitated product was filtered off and washed with a small amount of cold water, followed by cold ethanol to yield purine 6-sulfenamide $\mathbf{1 0 a}-\mathbf{c}, \mathbf{1 0 e}$. The crude products were purified by a column chromatography (silica gel, $\left.\mathrm{CHCl}_{3}, \mathrm{CHCl}_{3}-\mathrm{EtOH}, 99: 1 \mathrm{v} / \mathrm{v}\right)$. The aqueous filtrate separated after precipitation of product 10e was evaporated to dryness and extracted with absolute ethanol $(3 \times 5 \mathrm{ml})$. The ethanolic solvent was evaporated, and the residue was purified by column chromatography (aluminum oxide, $\left.\mathrm{CHCl}_{3}-\mathrm{EtOH}, 10: 1 \mathrm{v} / \mathrm{v}\right)$ to give compound $\mathbf{1 0 d}$.

2-Chloro-7-methyl-6-purinesulfenamide $10 a$ was obtained as a yellow solid $(0.35 \mathrm{~g}, 87.5 \%)$; mp $149-150{ }^{\circ} \mathrm{C}$ $\left(\right.$ EtOH); ${ }^{1} \mathrm{H}$ NMR (DMSO-d 6 ), $\delta: 3.98$ (s, 3H, $\left.\mathrm{NCH}_{3}\right), 4.41$ (s, 2H, $\mathrm{NH}_{2}$ ), 8.51 (s, 1H, H-8); ${ }^{13} \mathrm{C}$ NMR (DMSO-d 6 ), $\delta$ : $35.13\left(\mathrm{CH}_{3}, \mathrm{NCH}_{3}\right), 120.85(\mathrm{C}, \mathrm{C}-5), 150.41(\mathrm{CH}, \mathrm{C}-8)$, 152.99 (C, C-4), 159.88, 164.43 (C, C-2, and C-6); FABMS m/z $216[\mathrm{M}+1]^{+}$(38), $218[\mathrm{M}+1+2]$ (12), 185 (100); HREIMS m/z [M] ${ }^{+}$calcd. for $\mathrm{C}_{6} \mathrm{H}_{6} \mathrm{ClN}_{5} \mathrm{~S} 215.0032$ found 215.0029 .

2-Methoxy-7-methyl-6-purinesulfenamide $10 \mathrm{~b}$ was obtained as a yellow solid $(0.39 \mathrm{~g}, 92.5 \%)$; mp $158-159{ }^{\circ} \mathrm{C}$ $(\mathrm{EtOH}) ;{ }^{1} \mathrm{H}$ NMR (DMSO-d 6 ), $\delta: 3.93\left(\mathrm{~s}, 6 \mathrm{H}, \mathrm{OCH}_{3}\right.$, $\left.\mathrm{NCH}_{3}\right), 4.20\left(\mathrm{~s}, 2 \mathrm{H}, \mathrm{NH}_{2}\right), 8.30(\mathrm{~s}, 1 \mathrm{H}, \mathrm{H}-8) ;{ }^{13} \mathrm{C} \mathrm{NMR}$ $\left(\mathrm{DMSO}_{6}\right), \delta: 34.80\left(\mathrm{CH}_{3}, \mathrm{NCH}_{3}\right), 54.81\left(\mathrm{CH}_{3}, \mathrm{OCH}_{3}\right)$, 117.79 (C, C-5), 148.81 (CH, C-8), 160.55 (C, C-4), 161.72, 162.98 (C, C-2, and C-6); FABMS m/z 212 $[\mathrm{M}+1]^{+}$(100); HREIMS m/z $[\mathrm{M}]^{+}$calcd. for $\mathrm{C}_{7} \mathrm{H}_{9} \mathrm{~N}_{5} \mathrm{OS}$ 211.0527 found 211.0523 .

2-Methylthio-7-methyl-6-purinesulfenamide 10c was obtained as a yellow solid (0.385 g, $85 \%)$; mp $164-165{ }^{\circ} \mathrm{C}$ $\left(\right.$ EtOH); ${ }^{1} \mathrm{H}$ NMR (DMSO-d 6 ), $\delta: 2.57$ (s, 3H, $\mathrm{SCH}_{3}$ ), 3.94 $\left(\mathrm{s}, 3 \mathrm{H}, \mathrm{NCH}_{3}\right), 4.25\left(\mathrm{~s}, 2 \mathrm{H}, \mathrm{NH}_{2}\right), 8.35$ (s, 1H, H-8); ${ }^{13} \mathrm{C}$ NMR (DMSO-d $), \delta: 14.32\left(\mathrm{CH}_{3}, \mathrm{SCH}_{3}\right), 34.86\left(\mathrm{CH}_{3}\right.$, $\left.\mathrm{NCH}_{3}\right), 119.06(\mathrm{C}, \mathrm{C}-5), 151.57(\mathrm{CH}, \mathrm{C}-8), 159.32(\mathrm{C}$, C-4), 161.52, 164.01 (C, C-2, and C-6); FABMS m/z 228 $[\mathrm{M}+1]^{+}(100)$; HREIMS m/z [M] ${ }^{+}$calcd. for $\mathrm{C}_{7} \mathrm{H}_{9} \mathrm{~N}_{5} \mathrm{~S}_{2}$ 227.0299 found 227.0299 .

7-Methyl-6-sulfenamide-2-purinethione 10d was obtained as a yellow solid $(0.07 \mathrm{~g}, 16.5 \%)$; mp 254-256 ${ }^{\circ} \mathrm{C}$ $(\mathrm{EtOH}) ;{ }^{1} \mathrm{H}$ NMR (DMSO-d 6 ), $\delta: 4.20\left(\mathrm{~s}, 3 \mathrm{H}, \mathrm{NCH}_{3}\right), 4.37$ $\left(\mathrm{s}, 2 \mathrm{H}, \mathrm{NH}_{2}\right), 8.18(\mathrm{~s}, 1 \mathrm{H}, \mathrm{H}-8), 10.83(\mathrm{~s}, 1 \mathrm{H}, \mathrm{NH}) ;{ }^{13} \mathrm{C}$
NMR (DMSO-d $\left.{ }_{6}\right), \delta: 34.68\left(\mathrm{CH}_{3}, \mathrm{NCH}_{3}\right), 121.30(\mathrm{C}, \mathrm{C}-5)$, 147.96 (CH, C-8), 157.40 (C, C-4), 169.22, 173.95 (C, C-2, and C-6); FABMS m/z 214 [M+1] (100); HREIMS m/z $[\mathrm{M}]^{+}$calcd. for $\mathrm{C}_{6} \mathrm{H}_{7} \mathrm{~N}_{5} \mathrm{~S}_{2} 213.0143$ found 213.0141 .

7-Methyl-2,6-purinedisulfenamide $10 \boldsymbol{e}$ was obtained as a yellow solid $(0.315 \mathrm{~g}, 69 \%)$; mp $185-186{ }^{\circ} \mathrm{C}(\mathrm{EtOH}) ;{ }^{1} \mathrm{H}$ NMR $\left(\right.$ DMSO-d 6 ) $\delta: 3.94\left(\mathrm{~s}, 3 \mathrm{H}, \mathrm{NCH}_{3}\right), 4.03(\mathrm{~s}, 2 \mathrm{H}$, $\left.\mathrm{NH}_{2}\right), 4.18\left(\mathrm{~s}, 2 \mathrm{H}, \mathrm{NH}_{2}\right), 8.35(\mathrm{~s}, 1 \mathrm{H}, \mathrm{H}-8) ;{ }^{13} \mathrm{C} \mathrm{NMR}$ $\left(\mathrm{DMSO}_{6}\right), \quad \delta: 34.82\left(\mathrm{CH}_{3}, \mathrm{NCH}_{3}\right), 119.09$ (C, C-5), 148.72 (CH, C-8), 159.45 (C, C-4), 161.26, 169.60 (C-2 and C-6); HSQC NMR, $\delta$ : 8.35 (H-8) correlated with $148.72(\mathrm{C}-8), 3.94\left(\mathrm{H}, \mathrm{NCH}_{3}\right)$ correlated with $34.82(\mathrm{C}$, $\left.\mathrm{NCH}_{3}\right) ; \mathrm{HMBC}$ NMR, $\delta: 8.35(\mathrm{H}-8)$ correlated with 34.82 $\left(\mathrm{C}, \mathrm{NCH}_{3}\right), 119.09(\mathrm{C}-5)$, and $159.45(\mathrm{C}-4), 3.94(\mathrm{H}$, $\mathrm{NCH}_{3}$ ) correlated with $119.09(\mathrm{C}-5)$ and with $148.72(\mathrm{C}-8)$; FABMS m/z 229 [M+1] (100); HREIMS m/z [M] ${ }^{+}$calcd. for $\mathrm{C}_{6} \mathrm{H}_{8} \mathrm{~N}_{6} \mathrm{~S}_{2} 228.0252$ found 228.0255 .

\section{General synthesis of 2-substituted 7-methyl-6- purinesulfonamide $8 a-c, 8 e$}

A solution of 3-chloroperbenzoic acid (MCPBA) (77\%, $0.86 \mathrm{~g}, 4 \mathrm{mmol}$ ) in $10 \mathrm{ml}$ of ethanol was added dropwise for $10 \mathrm{~min}$ to a solution of sulfonamides $\mathbf{1 0 a}-\mathbf{c}$ and 10e ( $1 \mathrm{mmol})$ in $79 \mathrm{ml}$ of absolute ethanol. The mixture was stirred at room temperature for $1.5 \mathrm{~h}$, and a precipitated solid was filtered off to give crude products $\mathbf{8 a - c}$ and $8 \mathbf{e}$. The ethanolic filtrate was evaporated to dryness and extracted with ether to remove 3-chlorobenzoic acid. The solid residue together with crude product was purified by a column chromatography (aluminum oxide, $\mathrm{CHCl}_{3}, \mathrm{CHCl}_{3}-$ EtOH, 9:1 v/v) to give also compounds 8a-c, 8e.

2-Chloro-7-methyl-6-purinesulfonamide $8 a$ was obtained as a white solid $(0.18 \mathrm{~g}, 73 \%)$; mp $174-175^{\circ} \mathrm{C}(\mathrm{EtOH})$; ${ }^{1} \mathrm{H}$ NMR (DMSO-d ${ }_{6}$ ), $\delta: 4.07$ (s, 3H, $\left.\mathrm{NCH}_{3}\right), 6.91$ (s, 2H, $\mathrm{NH}_{2}$ ), 8.82 (s, 1H, H-8); ${ }^{13} \mathrm{C}$ NMR (DMSO-d $\left.{ }_{6}\right), \delta: 36.46$ $\left(\mathrm{CH}_{3}, \mathrm{NCH}_{3}\right), 121.55(\mathrm{C}, \mathrm{C}-5), 151.93(\mathrm{CH}, \mathrm{C}-8), 153.88$ (C, C-4), 160.39, 164.62 (C, C-2, and C-6); EIMS m/z 247 $[\mathrm{M}]^{+}$(1.5), $249[\mathrm{M}+2](0.5) ; 183$ [M-SO $]$ (14), 168 [M$\left.\mathrm{SO}_{2} \mathrm{NH}_{2}\right]$ (100); HREIMS m/z [M] ${ }^{+}$calcd. for $\mathrm{C}_{6} \mathrm{H}_{6}$ $\mathrm{ClN}_{5} \mathrm{O}_{2} \mathrm{~S} 246.9930$ found 246.9927 .

2-Methoxy-7-methyl-6-purinesulfonamide $8 \boldsymbol{b}$ was obtained as a white solid $(0.185 \mathrm{~g}, 76 \%)$; mp 203-204 ${ }^{\circ} \mathrm{C}$. $(\mathrm{EtOH}) ;{ }^{1} \mathrm{H}$ NMR $\left(\mathrm{DMSO}_{6}\right), \delta: 3.88\left(\mathrm{~s}, 3 \mathrm{H}, \mathrm{OCH}_{3}\right), 4.04$ $\left(\mathrm{s}, 3 \mathrm{H}, \mathrm{NCH}_{3}\right), 7.99\left(\mathrm{~s}, 2 \mathrm{H}, \mathrm{NH}_{2}\right), 8.70(\mathrm{~s}, 1 \mathrm{H}, \mathrm{H}-8) ;{ }^{13} \mathrm{C}$ NMR (DMSO-d $\left.)_{6}\right), \delta$ : $35.86\left(\mathrm{CH}_{3}, \mathrm{NCH}_{3}\right), 55.59\left(\mathrm{CH}_{3}\right.$, $\left.\mathrm{OCH}_{3}\right), 117.32(\mathrm{C}, \mathrm{C}-5), 133.80(\mathrm{CH}, \mathrm{C}-8), 153.60(\mathrm{C}$, C-4), 157.55, 166.54 (C, C-2, and C-6); EIMS m/z 243 $[\mathrm{M}]^{+}(26), 180\left[\mathrm{M}-\mathrm{SO}_{2}\right]$ (55.5), $162\left[\mathrm{M}-\mathrm{SO}_{2} \mathrm{NH}_{2}\right]$ (8), 148 (100); HREIMS m/z [M] $]^{+}$calcd. for $\mathrm{C}_{7} \mathrm{H}_{9} \mathrm{~N}_{5} \mathrm{O}_{3} \mathrm{~S} 243.0426$ found 243.0419 . 
2-Methylthio-7-methyl-6-purinesulfonamide $8 c$ was obtained as a white solid (0.17 g, $66 \%)$; mp $198-199{ }^{\circ} \mathrm{C}$ $(\mathrm{EtOH}) ;{ }^{1} \mathrm{H}$ NMR (DMSO-d 6 ), $\delta: 2.56$ (s, 3H, $\left.\mathrm{SCH}_{3}\right), 4.03$ $\left(\mathrm{s}, 3 \mathrm{H}, \mathrm{NCH}_{3}\right), 7.86\left(\mathrm{~s}, 2 \mathrm{H}, \mathrm{NH}_{2}\right), 8.75$ (s, $\left.1 \mathrm{H}, \mathrm{H}-8\right) ;{ }^{13} \mathrm{C}$ NMR (DMSO-d $), \delta: 15.59\left(\mathrm{CH}_{3}, \mathrm{SCH}_{3}\right), 34.04\left(\mathrm{CH}_{3}\right.$, $\left.\mathrm{NCH}_{3}\right), 116.45(\mathrm{C}, \mathrm{C}-5), 129.28(\mathrm{CH}, \mathrm{C}-8), 133.20(\mathrm{C}$, C-4), 147.01, 166.54 (C, C-2, and C-6); CIMS m/z 260 $[\mathrm{M}+1](22), 196\left[\mathrm{M}+1-\mathrm{SO}_{2}\right](64), 180\left(\mathrm{M}+1-\mathrm{SO}_{2} \mathrm{NH}_{2}\right]$ (100); HREIMS $\mathrm{m} / \mathrm{z}[\mathrm{M}]^{+}$calcd. for $\mathrm{C}_{7} \mathrm{H}_{9} \mathrm{~N}_{5} \mathrm{O}_{2} \mathrm{~S}_{2}$ 259.0198 found 259.0195 .

7-Methyl-2,6-purinedisulfonamide $8 \boldsymbol{d}$ was obtained as a white solid $(0.23 \mathrm{~g}, 79 \%)$; mp $214-215^{\circ} \mathrm{C}(\mathrm{EtOH}) ;{ }^{1} \mathrm{H}$ NMR (DMSO-d $\left.)_{6}\right), \delta: 4.17\left(\mathrm{~s}, 3 \mathrm{H}, \mathrm{NCH}_{3}\right), 7.01(\mathrm{~s}, 2 \mathrm{H}$, $\mathrm{NH}_{2}$ ), 7.69 (s, 2H, $\mathrm{NH}_{2}$ ), 8.97 (s, 1H, H-8); ${ }^{13} \mathrm{C} \mathrm{NMR}$ $\left(\mathrm{DMSO}_{6}\right), \delta: 36.30\left(\mathrm{CH}_{3}, \mathrm{NCH}_{3}\right), 122.52(\mathrm{C}, \mathrm{C}-5)$, 154.76 (CH, C-8), 158.11 (C, C-4), 159.98, 162.99 (C, C-2, and C-6); EIMS m/z $292\left[\right.$ [M] $^{+}$(9), $229\left(\mathrm{M}-S O_{2}\right]$ (7), 149 [M-SO $\mathrm{NH}_{2}$ ] (22), 57 (100); HREIMS m/z [M] ${ }^{+}$calcd. for $\mathrm{C}_{6} \mathrm{H}_{8} \mathrm{~N}_{6} \mathrm{O}_{4} \mathrm{~S}_{2} 292.0048$ found 292.0044 .

\section{Antiproliferative assay in vitro}

\section{Cell culture}

Compounds were evaluated for their anticancer activity using three cultured cell lines: SNB-19 (human glioblastoma, DSMZ - German Collection of Microorganisms and Cell Cultures, Braunschweig, Germany), C-32 (human amelanotic melanoma, ATCC-American Type Culture Collection, Manassas, VA, USA), T47D (human ductal breast epithelial tumor cell line, ATCC, Manassas, VA, USA), and HFF-1 (human fibroblast cell line, ATCC, Manassas, VA, USA). The cultured cells were kept at $37{ }^{\circ} \mathrm{C}$ and $5 \% \mathrm{CO}_{2}$. The cells were seeded $\left(1 \times 10^{4}\right.$ cells/well/100 $\mu \mathrm{l}$ DMEM supplemented with $10 \% \mathrm{FCS}$ and streptomycin and penicillin) using 96-well plates (Corning).

\section{Proliferation}

In recent years, tetrazolium salts have been described which can be used for the measurement of cell proliferation and viability. The tetrazolium salts are cleaved to formazan by cellular enzymes. An expansion in the number of viable cells results in an increase in the overall activity of mitochondrial dehydrogenases in the sample. This augmentation in enzyme activity leads to an increase in the amount of formazan dye formed, which directly correlates with the number of metabolically active cells in the culture. The formazan dye produced by metabolically active cells is quantified by a scanning ELISA reader by measuring the absorbance of the dye solution at appropriate wavelengths
( $\lambda=420-480 \mathrm{~nm} \quad$ with a reference wavelength $\lambda=600 \mathrm{~nm})$.

\section{WST-1 assay}

Antiproliferative effect of compounds was determined using the Cell Proliferation Reagent WST-1 assay (Roche Diagnostics, Mannheim, Germany). After exposure to tested compounds (at concentrations between 0 and $100 \mu \mathrm{g} / \mathrm{ml}$ ) for $72 \mathrm{~h}$, cells were incubated with WST-1 $(10 \mu \mathrm{l})$ for $1 \mathrm{~h}$, and the absorbance of the samples against a background control was read at $450 \mathrm{~nm}$ using with a reference wavelength $\lambda=600 \mathrm{~nm}$ a microplate reader. $\mathrm{Re}$ sults are expressed as means of at least two independent experiments performed in triplicate.

Acknowledgments The synthesis and the structure elucidation are supported by the Medical University of Silesia (Grant KNW-1-004/K/ $4 / 0)$.

Open Access This article is distributed under the terms of the Creative Commons Attribution License which permits any use, distribution, and reproduction in any medium, provided the original author(s) and the source are credited.

\section{References}

Adams RR, Whitmore FC (1945) Heterocyclic basic compounds. Dialkylaminoalkylaminopurines. J Am Chem Soc 67:1271-1273

Aldinucci A, Biagioli T, Manuelli C, Repice AM, Massacesi L, Ballerini C (2010) Modulating dendritic cells (DC) from immunogenic to tolerogenic responses. J Neuroimmunol 218:28-35

Ashfaq M, Shah SSA, Najjam T, Shaheen S, Riviera G (2013) Synthetic routes of sulfonamide derivatives; a brief review. Mini Rev Org Chem 10:160-170

Azab ME, Youssef MM, El-Bordany EA (2013) Synthesis and antibacterial evaluation of novel heterocyclic compounds containing a sulfonamide moiety. Molecules 18:832-844

Beaman AG (1963) Heterocyclic nitrogen compounds containing sulfonyl fluoride groups and method of producing some. USA Patent 3(074):948

Beaman AG, Robins RK (1961) Potential purine antagonists. Synthesis and reactions of some purinesulfonyl fluorides. J Am Chem Soc 83:4038-4044

Beaman AG, Tantz W, Duschinsky R, Grunberg E (1966) Purine sulfonamides. J Med Chem 9:373-378

Brathe A, Gundersen LL, Nissen-Meyer J, Rise F, Spilsberg B (2003) Cytotoxic activity of 6-alkynyl- and 6-alkenylpurines. Bioorg Med Chem Lett 13:877-880

Broom AD, Gall AA, Meyer RB (1997) Oligonucleotides containing n-methyl thiolated bases having antiviral activity. US Patent $5652359 \mathrm{~A}$

Chang-Hyun O, Hee-Kwon K, Su-Chul L, Changsok O, Boem-Seok Y, Seok RJ (2001) Synthesis and biological propertis of C-2, C-8, N-9 substituted 6-(3-chloroanilino)-purine derivatives cyclin-dependent kinase inhibitors. Arch Pharm Med Chem $334: 345-350$ 
Colombel JF, Sandborn WJ, Reinisch W, Mantzaris GJ, Kornbluth A, Rachmilewitz D, Lichtiger S, D'Haens G, Diamond RH, Broussard DL, Tang KI, van der Wande CJ, Rutgeerts P (2010) Infliximab, azathioprine, or combination therapy for Crohn's disease. N Engl J Med 362:1383-1395

Corrales RCNR, de Souza NB, Pinheiro LS, Abramo C, Coimbra ES, da Silva AD (2011) Thiopurine derivatives containing triazole and steroid: synthesis, antimalarial and antileishmanial activities. Biomed Pharmacother 65:198-203

Daehn EI, Karran P (2009) Immune effector cells produce lethal DNA damage in cells treated with a thiopurine. Cancer Res 69:2393-2399

El-Sayed NS, El-Bendary ER, El-Ashry SM, El-Kerdawy MM (2011) Synthesis and antitumor activity of new sulfonamide derivatives of thiadiazolo[3,2- $\alpha]$ pyrimidines. Eur J Med Chem 46:37143720

Guzel O, Innocenti A, Scozzafava A, Salman A, Supuran CT (2009) Carbonic anhydrase inhibitors. Phenacetyl-, pyridylacetyl- and thienylacetyl substituted aromatic sulfonamides act as potent and selective isoform VII inhibitors. Bioorg Med Chem Lett 19:3170-3173

Harada $\mathrm{H}$, Asano $\mathrm{O}$, Kawata $\mathrm{T}$, Inoue $\mathrm{T}$, Horizoe $\mathrm{T}$, Yasuda $\mathrm{N}$, Nagata K, Murakami M, Nagaoka J, Kobayashi S, Tanaka I, Abe S (2001) 2-Alkynyl-8-aryladenines possessing an amide moiety: their synthesis and structure-activity relationships of effects on hepatic glucose production induced via agonism of the $\mathrm{A}_{2 \mathrm{~B}}$ adenosine receptor. Bioorg Med Chem 9:2709-2726

Hawwa AF, Collier PS, Millership JS, McCarthy A, Dempsey S, Cairns C, McElnay JC (2008) Population pharmacokinetic and pharmacogenetic analysis of 6-mercaptopurine in paediatric patients with acute lymphoblastic leukaemia. Br J Clin Pharmacol 66:826-837

Hurley TJ, Robinson MA (1965) The reaction of chloramine with mercaptopyrimidine and mercaptopyrimidine derivatives. J Med Chem 8:888-889

Joseph P, Turtant F, Ouahrani-Bettache S, Montero JL, Nishimori I, Minakuchi T, Vullo D, Scozzafava A, Kohler S, Winum JY, Supuran CT (2010) Cloning, characterization, and inhibition studies of a $\beta$-carbonic anhydrase from Brucelle suis. J Med Chem 53:2277-2285

Kowalska A, Pluta K (2008) Synthesis of the azathioprine analogs. Heterocycles 75:555-569

Kowalska A, Pluta K (2012) Synthesis of 2- and 6-(dialkylaminoalkylthio)- and 2,6-bis(dialkylaminoalkylthio)-7-methylpurines. Heterocycles 85:2473-2483

Kowalska A, Pluta K, Suwińska K (2009) Synthesis of isomeric analogs of azathioprine. Heterocycles 78:2455-2466

Lech-Maranda E, Robak E, Korycka A, Robak T (2006) Pharmacological and clinical studies on purine nucleoside analogs-new anticancer agents. Mini Rev Med Chem 6:575-581

Mirian M, Zarghi A, Sadeghi S, Tabaraki P, Tavallaee M, Dadrass O, Sadeghi-aliabadi H (2011) Synthesis and cytotoxic evaluation of some novel sulfonamide derivatives against a few human cancer cells. Iran J Pharm Res 10:741-748

Miron T, Arditti F, Konstantinovski L, Rabinkov A, Mirelman D, Berrebi A, Wilchek M (2009) Novel derivatives of 6-mercaptopurine: synthesis, characterization and antiproliferative activities of S-allylmercaptopurines. Eur J Med Chem 44:541-550
Narasaiah T, Rao DS, Ramana KV, Adam S, Raju CN (2012) Synthesis of new sulfonamide derivatives of tryptamine and their antimicrobial activity. Der Pharma Chem 4:1582-1590

Prima FD, Shenoy A, Moses SR, Shabaraya AR (2013) Antitumor activity of mercaptopurine in combination with trikatu and gomutra on 20-methylcholantrene induced carcinogenesis. J App Pharm Sci 3:20-23

Rao PV, Ravindhranath K, Kumar KR (2013) Antibacterial activity of novel substituted mercaptopurine derivatives. Inst $\mathrm{J}$ Pharm Biomed Res 4:127-131

Rehman A, Afroz S, Abbasi MA, Tanveer W, Khan KM, Ashraf M, Ahmad I, Afzal I, Ambreen N (2012) Synthesis, characterization and biological screening of sulfonamides derived form 2-phenylethylamine. Pak J Pharm Sci 25:809-814

Relling MV, Gardner EE, Sandborn WJ, Schmiegelow K, Pui CH, Yee SW, Stein CM, Carrillo M, Evans WE, Hicks JK, Schwab M, Klein TE (2013) Clinical pharmacogenetics implementation consortium guidelines for thiopurine methyltransferase genotype and thiopurine dosing. Clin Pharmacol Ther 93:324-325

Revankar GR, Hanna NB, Imamura N, Lewis AF, Larson SB, Finch RA, Avery TL, Robins RK (1990) Synthesis and in vivo antitumor activity of 2-amino-9H-purine-6-sulfenamide, -sulfinamide, and sulfonamide and related purine ribonucleosides. J Med Chem 33:121-128

Robins RK, Revankar GR, Hanna NB (1991) 6-Sulfenamide, 6-sulfinamide and 6-sulfonamide purines, purine nucleosides, purine nucleotides, pharmaceutical compositions, and processes of making. USA Patent 5(026):836

Schoenwald RD, Eller MG, Dixon JA, Barfknecht CF (1984) Topical carbonic anhydrase inhibitors. J Med Chem 27:810-812

Schow SR, Mackman RL, Blum CL, Brooks E, Horsma AG, Joly A, Kerwar SS, Lee G, Shiffman D, Nelson MG, Wang X, Wick MM, Zhang X, Lum RT (1997) Synthesis and activity 2,6,9trisubstituted purines. Bioorg Med Chem Lett 7:2697-2702

Sławiński J, Szafrański K, Vullo D, Supuran CT (2013) Carbonic anhydrase inhibitors. Synthesis of heterocyclic 4-substituted pyridine-3-sulfonamide derivatives and their human cytosolic isozymes I and II and transmembrane tumor-associated isozymes IX and XII. Eur J Med Chem 69:701-710

Steurer M, Pall G, Richards S, Schwarzer G, Bohlius J, Greil R (2006) Single-agent purine analogues for the treatment of chronic lymphocytic leukaemia: a systematic review and meta-analysis. Cancer Treat Rev 32:377-389

Veisi H, Ghorbani-Vaghei R, Mahmoodi J (2011) Poly $\left(N, N^{\prime}\right.$ dichloro- $N$-ethyl-benzene-1,3-disulfonamide) and $N, N, N^{\prime}, N^{\prime}$ tetrachlorobenzene-1,3-disulfonamide as efficient reagents to direct oxidative conversion of thiols and disulfide to sulfonyl chlorides. Bull Korean Chem Soc 32:3692-3695

Volpini R, Costanzi S, Lambertucci C, Vittori S, Klotz KN, Lorenzen A, Cristalli G (2001) Introduction of alkynyl chains on C-8 of adenosine led to very selective antagonists of the $\mathrm{A}_{3}$ adenosine receptor. Bioorg Med Chem Lett 11:1931-1934

Zablocki AJ, Palle VP, Elzein EO, Nudelman G (2001) Propargyl phenyl ether $A_{2 A}$ receptor agonists. US Patent $6180615 \mathrm{~B} 1$

Zinic B, Krizmanic I, Vikic-Topic D, Srzic D, Zinic M (2001) Synthesis, NMR and MS study of novel N-sulfonylated purine derivatives. Croat Chem Acta 74:399-414 